Received $\quad 06.05 .2016$

Reviewed $\quad 02.07 .2016$

Accepted 04.10.2016

A - study design

B - data collection

C - statistical analysis

D - data interpretation

$\mathbf{E}$ - manuscript preparation

F - literature search

\section{Using artificial neural network (ANN) for prediction of sediment loads, application to the Mellah catchment, northeast Algeria}

\author{
Housseyn BOUZERIA ${ }^{1) ~ B C D E F ~} \bowtie$, \\ Abderrahmane N. GHENIM ${ }^{1) \text { ADEF }}$, Kamel KHANCHOUL ${ }^{2)}$ ADEF
}

1) University of Tlemcen, Faculty of Technology, Department of Hydraulics, BP 230 Chetouane Tlemcen 13000, Algeria;
e-mail: h.bouzeria@gmail.com, anghenim@yahoo.fr
${ }^{2)}$ University of Annaba, Soils and Sustainable Development Laboratory, Annaba, Algeria; e-mail: kkhanchoul@yahoo.fr

For citation: Bouzeria H., Ghenim A.N., Khanchoul K. 2017. Using artificial neural network (ANN) for prediction of sediment loads, application to the Mellah catchment, northeast Algeria. Journal of Water and Land Development. No. 33 p. 47-55. DOI: 10.1515/jwld-2017-0018.

\begin{abstract}
In this study, we present the performances of the best training algorithm in Multilayer Perceptron (MLP) neural networks for prediction of suspended sediment discharges in Mellah catchment. Time series data of daily suspended sediment discharge and water discharge from the gauging station of Bouchegouf were used for training and testing the networks. A number of statistical parameters, i.e. root mean square error (RMSE), mean absolute error $(M A E)$, coefficient of efficiency $(C E)$ and coefficient of determination $\left(R^{2}\right)$ were used for performance evaluation of the model. The model produced satisfactory results and showed a very good agreement between the predicted and observed data. The results also showed that the performance of the MLP model was capable to capture the exact pattern of the sediment discharge data in the Mellah catchment.
\end{abstract}

Key words: $A N N$ models, discharge, Mellah catchment, $M L P$, north east of Algeria, prediction, sediment

\section{INTRODUCTION}

The estimation of suspended sediment is an extremely difficult task because it is closely related to flow and the mechanism of their non-linear relationship and their complex interactions with each other KISI et al. [2012]. To estimate sediment concentrations and understand mechanisms of sediment movement in the natural rivers using different soft computing techniques, many studies have been performed MUSTAFA et al. [2011], KAKAEI LAFDANI et al. [2013], LIU et al. [2013], MUSTAFA and ISA [2014], DEMIRCI et al. [2015]. Establishment of rating relationship between flow and suspended sediment concentration is basically a non-linear mapping problem. The statistical tools that are commonly used in such situations are curve fitting and regression. However, in view of the complexity of the problem these tech- niques are not adequate KISI [2010]. In this way several techniques are available for time series analysis, which assume a linear relationship between the variables. But in reality, the temporal changes in data exhibit a complex non-linear behaviour and any accurate prediction remains difficult. Hence, it requires a nonlinear model like artificial neural networks, which is able to capture the complex temporal variations in time series data, easier to use and produce results faster than most conventional CIGIZOGLU [2004], SARANGi [2005], SAHOO [2006], AlP and CigIzOGLU [2007], KHANCHOUL et al. [2015].

ANN techniques have been successfully applied in various fields of engineering such as the hydrological sciences, particularly in the context of hydrological forecasting. RAI and MATHUR [2008], RAJAEE [2009], MAIER [2010], MELESSE et al. [2011], CHANG [2012], RAJAEE et al. [2011], MUSTAFA et al. [2012]. 
ANN techniques have been applied successfully for estimating and forecasting daily suspended sediments, modelling rivers sediment yields, estimation of reservoirs sedimentation, and prediction of sediment concentration in rivers MUSTAFA et al. [2011]. JAIN [2001] used a single ANN approach to establish daily sediment-discharge relationship and found that the ANN model could perform better than the rating curve. TAYFUR [2002] developed an ANN model for sheet sediment transport and indicated that the ANN could perform as well as, in some cases better than, the physically-based models. NAGY et al. [2002] used a feed-forward three-layer back propagation (BP) ANN model to predict the sediment concentration in rivers using eight input parameters reflecting sediment and riverbed information. CigIzogLU [2004] estimated suspended sediments in rivers using multiple linear regression model, stochastic autoregressive model, sediment rating curve and MLP neural networks. He suggested that the MLP model was better than the rest of the models. KISI [2005] developed an ANN model for modelling daily suspended sediment and compared the ANN results with those of the rating curve. CIGIZOGLU [2006] developed some methods to improve ANN performance in daily suspended sediment estimation. ALP, CigIzOGLU [2007] estimated suspended sediments by two different ANN techniques, feed forward neural networks and radial basis function, using hydro meteorological data. COBANER [2009], estimated suspended sediment concentration by an adaptive neuro-fuzzy and compared the results with three different artificial neural networks (ANN) techniques, namely, the generalized regression neural networks (GRNN), radial basis neural networks (RBNN) and multi-layer perceptron (MLP) and two different sediment rating curves (SRC). Recently, KISI [2010] proposed neural differential evolution models as an alternative to BP algorithms for suspended sediment estimation.

MUSTAFA et al. [2011] compared predictive performance of Radial Basis Function (RBF) and MultiLayer Feed Forward (MLFF) neural networks for prediction of suspended sediment discharge in rivers using only time series data of water discharge as input. They showed that both RBF and MLFF networks could be modeled for prediction of suspended sediment discharge by using only water discharge data. MELESSE et al. [2011] investigated the accuracy of a single ANN in estimation and forecasting of daily suspended sediment data. KAKAEI LAFDANI et al. [2013] predicted daily SSL using two data-driven techniques, support vector machines and artificial neural networks based on the abilities of GT for dealing with tasks of selecting the best combination of model inputs and number of data points required for model training phase. MUSTAFA and IsA [2014] presented a thorough comparison between the performances of Radial Basis Functions (RBF) and the Multilayer Perceptron (MLP) neural networks for estimation of suspended sediment in the Pari River, Perak,
Malaysia. The results showed that the performances of both particular RBF and MLP models were close to each other and capable to capture the exact pattern of the sediment data in the river. OLYAIE et al. [2015] compared the accuracy of three different soft computing methods, namely, artificial neural networks (ANNs), adaptive neuro-fuzzy inference system (ANFIS), coupled wavelet and neural network (WANN), and conventional sediment rating curve (SRC) approaches for estimating the daily SSL in two gauging stations in the USA.

The aim of this study is concerned with the application of Artificial Neural Network (ANN) model for predicting and estimating suspended sediment discharge in the Mellah catchment. Available data are used for evaluating the performance of the model, including different combinations as input and only suspended sediment discharge as output, from the gauging station of Bouchegouf for a duration period between 1970 and 2000 .

\section{ARTIFICIEL NEURAL NETWORK}

The ANN is a numerical modelling technique which is able to capture the complex non-linear relationships between input and output parameters. It's also applicable in all the situations where there is a nonlinear relation between a predictive variable and a predicted variable. In practice, the ANN architecture consists of an input layer, intermediate layers (hidden layer) and the output layer. The hidden layers may be one or more depending on the data type and the model error statistics. Also, the number of nodes in the hidden layer play a significant role in ANN model performance JAIN [2001]. Unfortunately, there are no exact rules about the number of neurons in the hidden layer. However, several authors consider that networks with the number of hidden nodes being equal to the number of input nodes are reported to have better forecasting results in several studies. Of the many ANN paradigms, the multi-layer feed-forward network (MLP), also the most popular KISI [2005; 2008], CIGIZOGLU [2006], TAYFUR and GULDAL [2006], ARDiÇLIOĞLU et al. [2007] are used in the present study.

A multilayer perceptron (MLP) is a feedforward artificial neural network model that maps sets of input data into a set of appropriate outputs. It utilizes a supervised learning technique called backpropagation for training the network. As shown in Figure 1 an MLP consists of multiple layers of nodes in a directed graph, with each layer fully connected to the next one. So the neurons are organized in successive layers: an input layer, an output layer and between the two one or several intermediate layers, also called hidden layers. The input, hidden, and output layer(s) receive signals from the input data, process the signals, and produce the output, respectively. There is no connection between the neurons in the same layer; on the other hand, any neuron in a layer is connected to all the neurons in the next layer with synaptic (weight) links. 


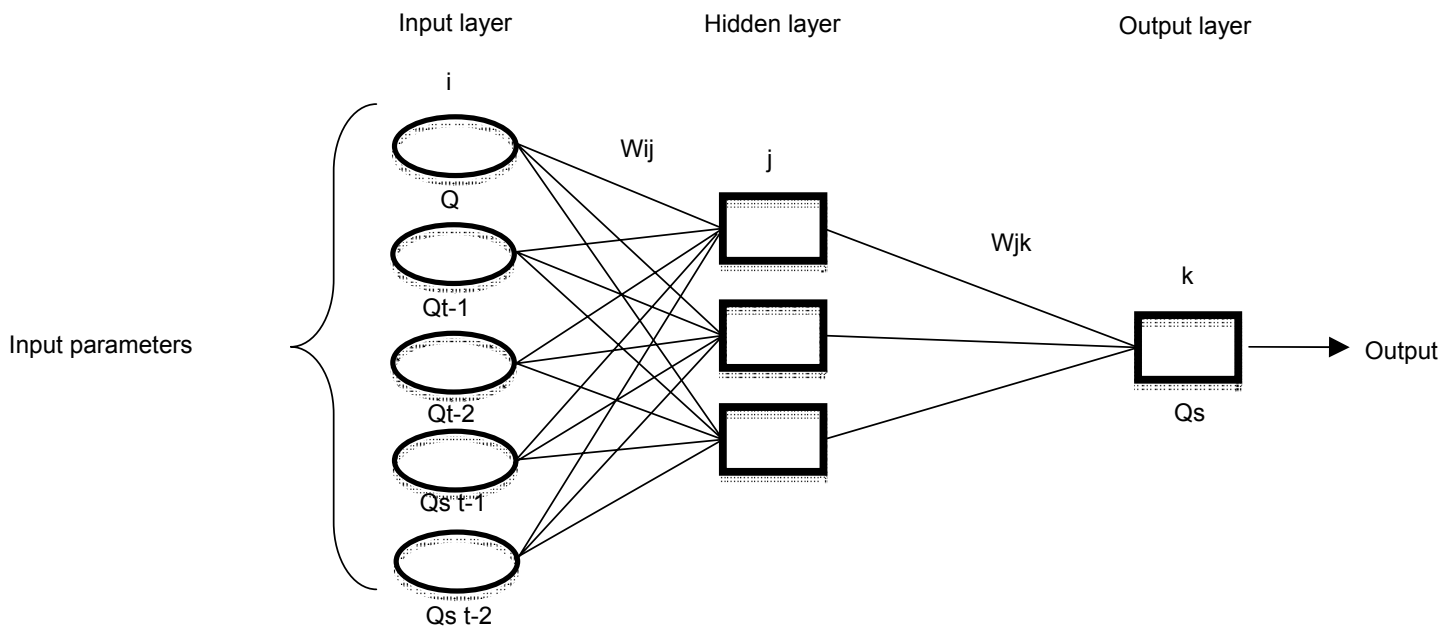

Fig. 1. Multilayer feed forward neural network architecture; source: own elaboration

Synapse or connection weight determines the strength of the signal of a neuron received by the neuron in the next layer SAHOO et al. [2006]. These weighted inputs are further added up and produce the argument for a transfer function such as a linear, logistic or hyperbolic tangent function which in turn produces the final output of the neuron. The input layer is not a real layer of neurons because it simply encodes the variables of observation. The output layer codes the variable of discrimination. The values of activity of neurons are propagated on the network, from input to output, without return rear. The presence of a hidden layer allows modelling of non-linear relationships between the inputs and the output. In theory a single hidden layer is sufficient, but the fact of having a second hidden layer allows you to model more easily a function of non-discrimination continues. In practice, most of the problems are solved with one or two levels, up to three.

\section{STUDY AREA}

The Mellah Wadi is the principal right bank affluent of Seybouse River which it joins with the outlet of the valley of Guelma. The basin, controlled by the Hydrometric Station of Bouchegouf occupies an area of $550 \mathrm{~km}^{2}$, which drains a mountainous area of the northern slope of the tell. It has an elongated shape with an orientation southwest-northeast (Fig. 2). By its topographic and morphometric characteristics, the basin can be decomposed into three differentiated zones: a) the upstream basin is essentially rugged and mountainous, with tops exceeding $1000 \mathrm{~m}$ (Djebel Enaouara 1279 m, Djebel Zouara $1226 \mathrm{~m}$ ); b) the middle basin is mountainous, but significantly less rugged; and c) the downstream basin presents less raised reliefs, as Djebel Boulergueb $(647 \mathrm{~m})$ and Djebel Eremoul $(829 \mathrm{~m})$. Nearly $70 \%$ of the watershed area is located at an altitude above $500 \mathrm{~m}$.

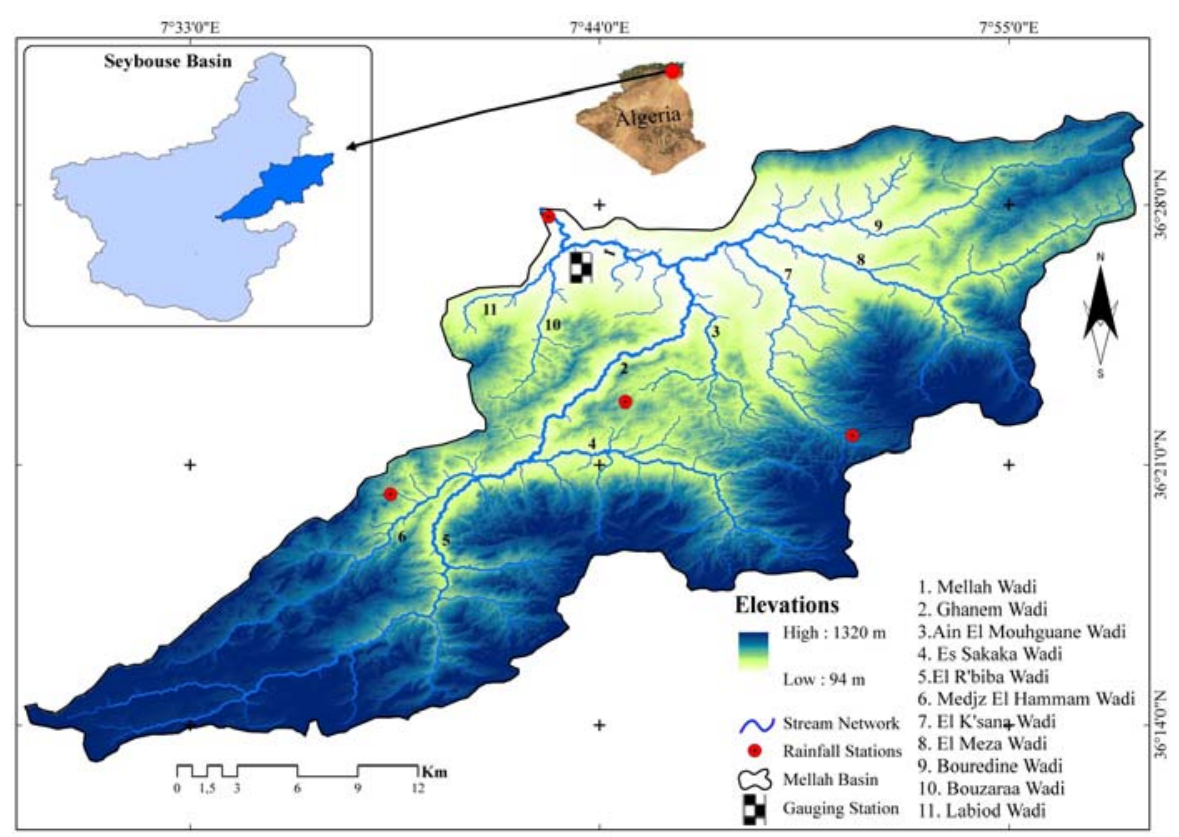

Fig. 2. Location map of the study area; source: own elaboration 
The Mellah watershed is mountainous. It includes relatively rugged terrain with slopes $(>30 \%)$, covering $30 \%$ of the basin area (southern part) and a high density hydrographic network. This mountainous landscape is a powerful stimulant to erosion.

The geology of the basin is represented by three main formations Figure 3, the alluvial deposits of Quaternary, which have a cardinal importance for the hydrogeology of the basin with their permeability, whose main accumulations are those of the Sfa Wadi, the R'Biba Wadi and the Medjz El Hammam Wadi. The two impermeable or semipermeable formations remaining constitute the borders of the natural basins. These formations are represented by the Numidian likings and the Triassic (index of Dj.Nador, and the Medjez Sfa).

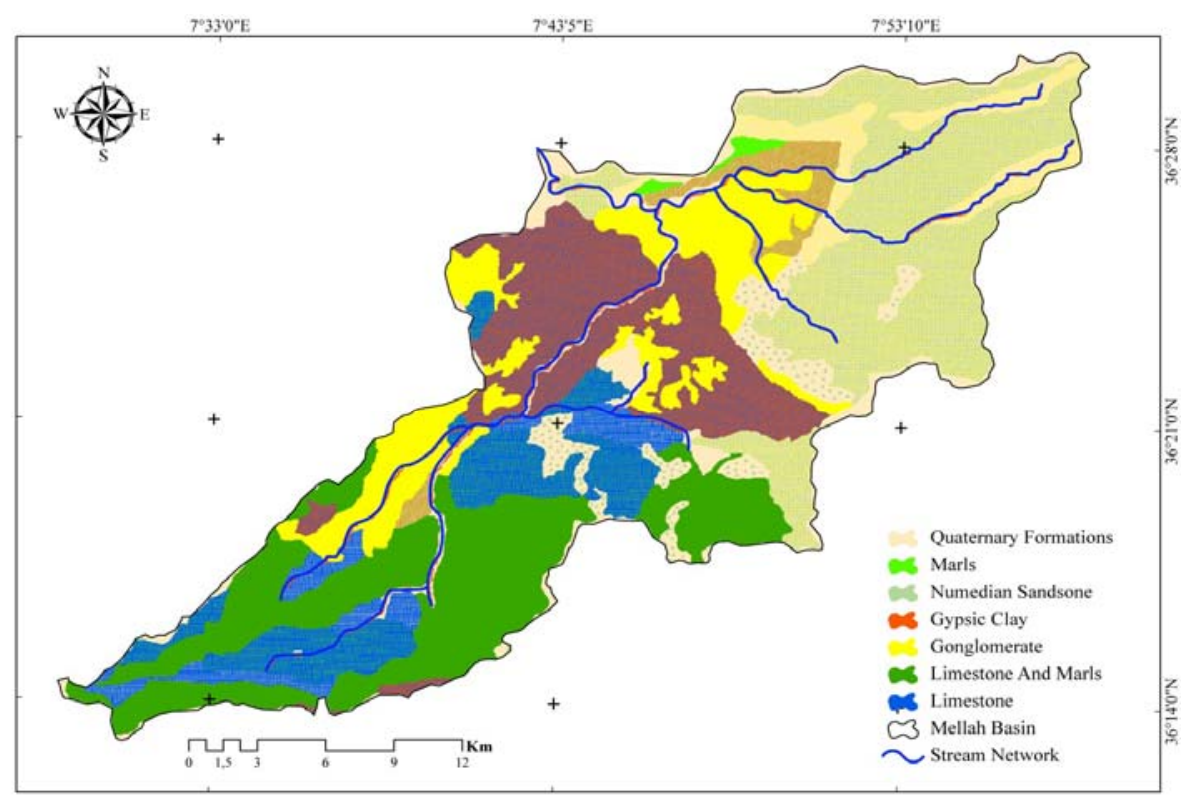

Fig. 3. Lithologic map of the Mellah catchment; source: own elaboration

The Mellah basin is subjected to a Mediterranean climate characterized by two distinct seasons: a slightly fresh winter and a hot dry summer from June to October. Mean annual rainfall variation recorded in this region in a period of 30 years is shown in Figure 4. It should be noted that of the 30 year period, the hydrological years 1973, 1996 and 1998 are the wettest with 825,812 and $810 \mathrm{~mm}$ respectively. While the years 1974, 1994 and 1996 were dry for values less than $350 \mathrm{~mm}$. At the monthly level, the highest values were recorded during the period from October to May with a maximum of $74 \mathrm{~mm}$ in January. These values decreased during the period from

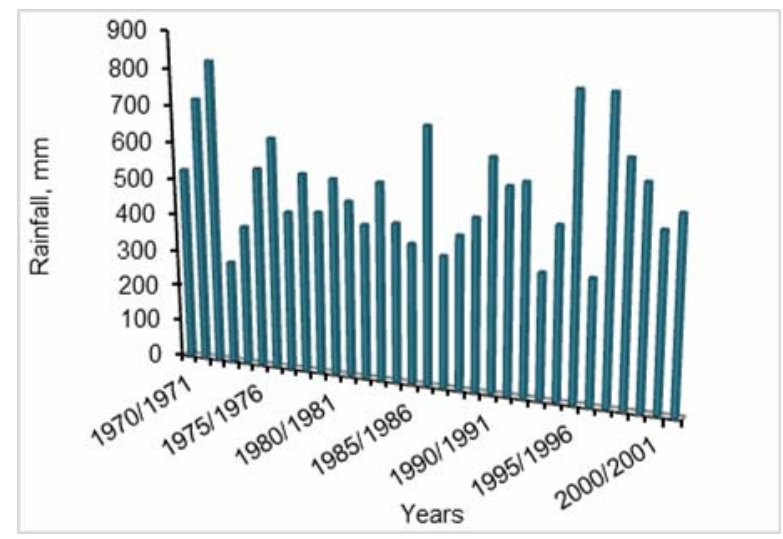

Fig. 4. Mean annual rainfall variation; source: own study
June to September with a height of $3 \mathrm{~mm}$ recorded in July Figure 5.

The distribution of monthly mean flows registered in the hydrometric station of Bouchegouf in a spread period 1970 to 2000 , is presented in the Figure 6. The gauging results of the Mellah Wadi indicate a decrease of flows $\left(0.26,0.19,0.28 \mathrm{~m}^{3} \cdot \mathrm{s}^{-1}\right)$ for the months of July, August and September. This period shows a correlation between the flow and precipitation. The maximal flows are encountered in the months of January, February and March with values $6.20,9.61$ and $6.42 \mathrm{~m}^{3} \cdot \mathrm{s}^{-1}$ respectively.

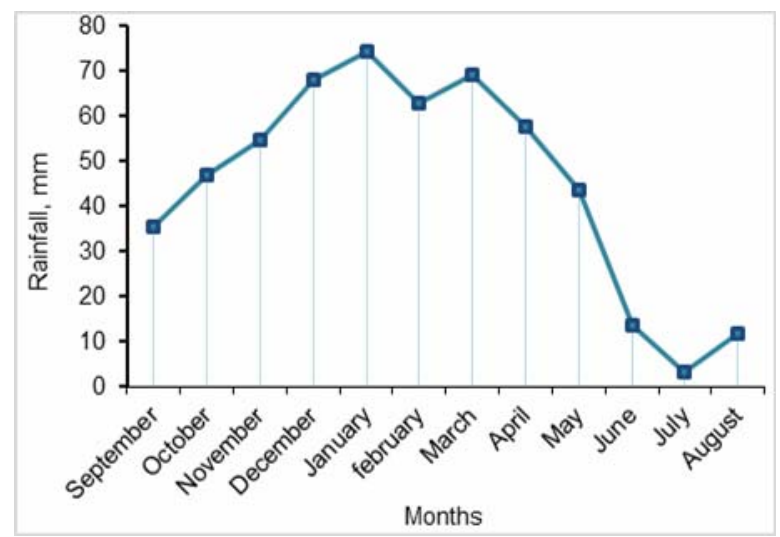

Fig. 5. Mean monthly rainfall distribution; source: own study 


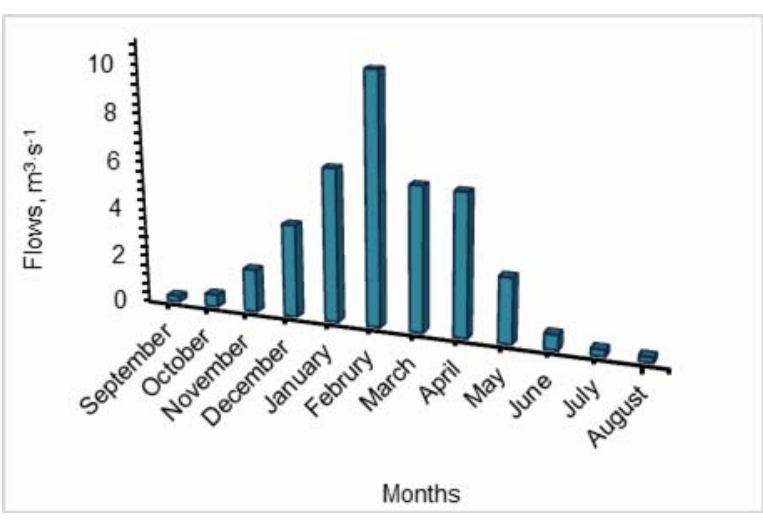

Fig. 6. Mean annual flow distribution; source: own study

\section{DATA AND METHODS}

Time series data of daily water discharge $(Q)$, suspended sediment concentration $(C)$, and hourly water discharge (based on river stage) during floods at the Bouchegouf gauging station was used in this study (Fig. 7). These data available between 1970-1971 and 1999-2000 which include less than 5\% of gaps were tested for their quality control. They were collected and provided by the National Agency of Hydraulic Resources (ANRH), which operates the network of monitoring stations in Algeria.

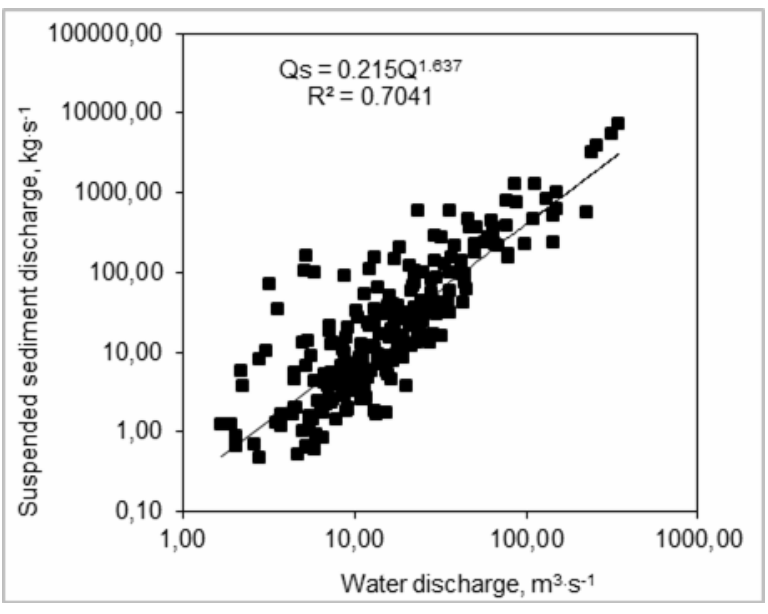

Fig. 7. Relationship between suspended sediment discharge and water discharge at the Mellah Wadi (1970-1971 to 1999-2000); source: own study

Daily mean water discharges were calculated as the mean of hourly water discharges. Suspended sediment concentration samples were collected in oneliter plastic bottles for laboratory analysis. The suspended sediment concentration of each sample was determined by the filtration method. It consists of filtering water on a filter membrane in order to retain all the particles of size larger than $0.5 \mu \mathrm{m}$. The collected particles were dried in an oven for 30 minutes at a temperature of $105^{\circ} \mathrm{C}$ and weighed. The concentration of suspended sediment in $\mathrm{mg} \cdot \mathrm{dm}^{-3}$ is the ratio of weighing dry mass and volume of the filtered water. It was assumed that the addition of dissolved solids to the suspended sediment through evaporation was negligible. Sediment discharges were obtained, by multiplying the discharge $(Q)$ to the suspended sediment concentration $(C)$.

Mellah Wadi like many rivers in semi-arid regions has an irregular character. The sedimentary activity is not always proportional to the water runoff (Tab. 1). During the study period, the mean annual water discharge was about $3 \mathrm{~m}^{3} \cdot \mathrm{s}^{-1}$. The river carried an annual runoff between $30.3 \cdot 10^{6} \mathrm{~m}^{3}$ (1988-1989) and $409.4 \cdot 10^{6} \mathrm{~m}^{3}(1973-1974)$. For sediment load, the maximum of $1191.4 \cdot 10^{3}$ tons was recorded in 19971998 and the minimum $19.7 \cdot 10^{3}$ tons in $1987-1988$.

Table 1. Annual and monthly values of runoff, suspended sediment load, concentration and suspended sediment yield at the Mellah Wadi (1970-1971 to 1999-2000)

\begin{tabular}{|c|c|c|c|c|}
\hline $\begin{array}{l}\text { Years/ } \\
\text { months }\end{array}$ & $\begin{array}{l}\text { Runoff } \\
10^{6} \mathrm{~m}^{3}\end{array}$ & $\begin{array}{c}\text { Suspended } \\
\text { sediment } \\
\text { load } \\
10^{3} \text { tons }\end{array}$ & $\begin{array}{c}\text { Concentra- } \\
\text { tion } \\
\mathrm{g} \cdot \mathrm{dm}^{-3}\end{array}$ & $\begin{array}{l}\text { Suspended } \\
\text { sediment } \\
\text { yield, } \mathrm{t} \cdot \mathrm{km}^{-2}\end{array}$ \\
\hline 1970-1971 & 112.0 & 259.6 & 2.3 & 472 \\
\hline 1971-1972 & 161.4 & 456.3 & 2.8 & 830 \\
\hline $1972-1973$ & 229.9 & 935.6 & 4.1 & 1701 \\
\hline 1973-1974 & 409.4 & 62.1 & 1.5 & 113 \\
\hline 1974-1975 & 76.5 & 269.2 & 3.5 & 489 \\
\hline 1975-1976 & 141.1 & 493.4 & 3.5 & 897 \\
\hline 1976-1977 & 49.6 & 77.0 & 1.5 & 140 \\
\hline $1977-1978$ & 73.4 & 140.7 & 1.9 & 256 \\
\hline 1978-1979 & 90.7 & 322.4 & 3.6 & 586 \\
\hline 1979-1980 & 46.7 & 80.1 & 1.7 & 146 \\
\hline 1980-1981 & 83.6 & 144.4 & 1.7 & 263 \\
\hline 1981-1982 & 92.3 & 169.7 & 1.8 & 309 \\
\hline $1982-1983$ & 49.1 & 66.7 & 1.4 & 121 \\
\hline 1983-1984 & 258.6 & 1191.4 & 4.6 & 2166 \\
\hline 1984-1985 & 132.9 & 339.5 & 2.5 & 617 \\
\hline 1985-1986 & 82.2 & 200.9 & 2.4 & 365 \\
\hline 1986-1987 & 185.5 & 499.4 & 2.7 & 908 \\
\hline 1987-1988 & 19.2 & 19.7 & 1.0 & 36 \\
\hline 1988-1989 & 30.3 & 37.7 & 1.2 & 69 \\
\hline 1989-1990 & 57.3 & 128.4 & 2.2 & 233 \\
\hline 1990-1991 & 141.0 & 384.5 & 2.7 & 699 \\
\hline 1991-1992 & 146.0 & 463.6 & 3.2 & 843 \\
\hline 1992-1993 & 91.7 & 225.9 & 2.5 & 411 \\
\hline 1994-1994 & 61.4 & 134.8 & 2.2 & 245 \\
\hline 1994-1995 & 77.4 & 165.0 & 2.1 & 300 \\
\hline 1995-1996 & 304.9 & 38.5 & 0.1 & 70 \\
\hline 1996-1997 & 47.7 & 101.0 & 2.1 & 184 \\
\hline 1997-1998 & 59.5 & 113.7 & 1.9 & 207 \\
\hline 1998-1999 & 56.9 & 101.0 & 1.8 & 184 \\
\hline 1999-2000 & 31.6 & 95.9 & 3.0 & 174 \\
\hline September & 21.6 & 15.1 & 0.7 & 27 \\
\hline October & 46.9 & 67.0 & 1.4 & 122 \\
\hline November & 125.4 & 442.2 & 3.5 & 804 \\
\hline December & 276.5 & 974.7 & 3.5 & 1772 \\
\hline January & 509.1 & 1355.2 & 2.7 & 2464 \\
\hline February & 705.7 & 1679.4 & 2.4 & 3053 \\
\hline March & 531.3 & 1503.8 & 2.8 & 2734 \\
\hline April & 472.7 & 1198.0 & 2.5 & 2178 \\
\hline May & 216.6 & 422.1 & 1.9 & 767 \\
\hline June & 49.4 & 40.3 & 0.8 & 73 \\
\hline July & 21.2 & 12.8 & 0.6 & 23 \\
\hline August & 15.1 & 7.6 & 0.5 & 14 \\
\hline
\end{tabular}

Source: own study. 
The annual average concentration varies from 0.1 to $4.6 \mathrm{~g} \cdot \mathrm{dm}^{-3}$. At the monthly level corresponding to the average year, the activity of the river is intense in the month of February where we recorded the maximum values while the minimum values were recorded in the month of August. Despite the irregularity in the behaviour of the river, the water and sediment discharges seem to be closely related (Fig. 7).

Different input combinations were tried to predict suspended sediment discharge values for the catchment. In all cases, we took different lag time series of discharge and suspended sediment discharge ( $Q t$, $Q s t-1, Q t-1, Q s t-2, Q t-2, Q s t+1, Q t+1)$ as input data and the output layer had only one neuron, that is, the sediment discharge $(Q s)$. The number of neurons in the hidden layer was investigated by trial and error method with variation between that for each combination to achieve the best network structure. So, for selecting the number of hidden nodes, we started with 1 hidden node and gradually increased the number until a network of 5 hidden nodes with the least mean squared error that was attained. Further increase in hidden nodes could produce high error and poor network performance MELESSE et al. [2011]. In all combinations the datasets were randomly divided into three subsets with equal proportions in the testing and validation sets, $70 \%$ were used for training, $15 \%$ and $15 \%$ were used to validate and test the network result.

\section{DATA NORMALIZATION}

Before applying the ANN to the data, the training input and output values should be normalized, because the most training algorithms are sensitive to the scale of the data. Generally, input and target data was preprocessed to scale the data between the ranges $(-1$, $1),(0.1,0.9)$, or $(0,1)$. Another approach is to rescale to a Gaussian function with a mean of 0 and unit standard deviation DAWSON and WILBY [2001]. In a feedforward back-propagation network, the weighted connections feed activations only in the forward direction from an input layer to the output layer. These interconnections are adjusted using an error convergence technique so that the network's response best matches the desired response. In general, the main advantage of the ANN technique over traditional methods is that it does not require information about the complex nature of the underlying process under consideration to be explicitly described in mathematical form WANG et al. [2009], OLYAIE et al. [2015]. In the present study, the input and output data have been scaled to make them bounded in the intervals 0 and +1 using the standardization equation as follows:

$$
Z_{i}=\frac{X_{i}-X_{\min }}{X_{\max }-X_{\min }}
$$

where: $Z_{i}$ is the normalized or transformed data series, $X_{i}$ is the original data series, $X_{\min }$ and $X_{\max }$ are the minimum and maximum of the dataset, respectively.
After training and testing results were achieved, the output values were de-normalized to get the output in the original scale of the data. The algorithm for the neural network model (MLP) was implemented using MATLAB.

\section{PERFORMANCE EVALUATION CRITERIA}

For investigating the performance of ANN model, different statistical measures, such as the root mean square error (RMSE), mean absolute error (MAE) and coefficient of efficiency $(C E)$, expressed by the following equations, were used:

$$
\begin{gathered}
R M S E=\left[\frac{1}{N} \sum_{n=1}^{N}\left(Q_{(s . \text { observed })}-Q_{(s . \text { predicted }) n}\right)^{2}\right]^{1 / 2} \\
M A E=\frac{1}{N} \sum_{n=1}^{N}\left|Q_{(s . \text { observed })}-Q_{(s . \text { predicted }) n}\right| \\
C E=1-\frac{\sum_{n=1}^{N}\left(Q_{(s . \text { observed }) n}-Q_{(s . \text { predicted }) n}\right)^{2}}{\sum_{n=1}^{N}\left(Q_{(s . \text { observed })}-\bar{Q}_{(\text {s.observed }) n}\right)^{2}}
\end{gathered}
$$

where: $Q_{(s . o b s e r v e d)}$ and $Q_{(s . \text { predicted })}$ are the observed and predicted values respectively, $Q_{\text {(s.observed) }}$ is the mean of observed values and $N$ is the total number of observations used for error computation. Ideally, the value of $R M S E$ and $M A E$ should be zero and $C E$ should be one. The advantage of RMSE and MAE is that the results of these models have the same unit and the same scale as the laboratory and numerical outputs. $C E$ provides a measure of how well the observed outcomes are replicated by the model.

\section{RESULTS AND DISCUSSION}

After the networks had been calibrated and validated, their performances were assessed with four statistics, the minimum root mean square error (RMSE), mean absolute error (MAE), coefficient of efficiency $(C E)$, and coefficients of correlation $\left(R^{2}\right)$. Table 2 shows the best network architecture and the related performance criteria for each combination. Also, the number of nodes of each combination with hidden layers and the training statistics of model in term of performance criteria are presented. According to the results, the ANN models provided the best performance criteria for combinations number 3, 6 and 7 , but we take choice for combination number 6 , because of its higher coefficient of correlation. In this combination $(Q, Q t-1, Q t-2, Q t+1)$, the ANN structure was the best for three hidden neurons.

Figure 8 shows the time series of observed and predicted suspended sediment during the training network. The model has learned precisely the nonlinear pattern of the suspended sediment discharge during the training and produced good generalization during the testing stage of the networks. In this study, time series of river discharge and sediment discharge 
Table 2. Best network architecture and the related performance criteria

\begin{tabular}{|c|l|c|c|c|c|c|c|}
\hline Combinations & \multicolumn{1}{|c|}{ Inputs } & Output & Neurons & $R M S E$ & $M A E$ & $C E$ & $R^{2}$ \\
\hline 01 & $Q$ & $Q s$ & 03 & 0.0206 & 0.01026313 & 0.95 & 0.97 \\
\hline 02 & $Q ; Q s t-1$ & $Q s$ & 02 & 0.0260 & 0.01066362 & 0.92 & 0.96 \\
\hline 03 & $Q ; Q t-1$ & $Q s$ & 03 & 0.0148 & 0.00772267 & 0.98 & 0.98 \\
\hline 04 & $Q ; Q t-1 ; Q t-2$ & $Q s$ & 02 & 0.0229 & 0.0093383 & 0.94 & 0.98 \\
\hline 05 & $Q ; Q t-1 ; Q s t-1$ & $Q s$ & 03 & 0.0273 & 0.01536833 & 0.92 & 0.96 \\
\hline 06 & $Q ; Q t-1 ; Q t-2 ; Q t+1$ & $Q s$ & 03 & 0.0131 & 0.00711802 & 0.98 & 0.99 \\
\hline 07 & $Q ; Q t-1 ; Q s t-1 ; Q t-2 ; Q s t-2$ & $Q s$ & 02 & 0.0131 & 0.00664598 & 0.98 & 0.98 \\
\hline
\end{tabular}

Explanations: $R M S E=$ root mean square error, $M A E=$ mean absolute error, $C E=$ coefficient of efficiency, $R^{2}=$ coefficient of correlation. Source: own study.

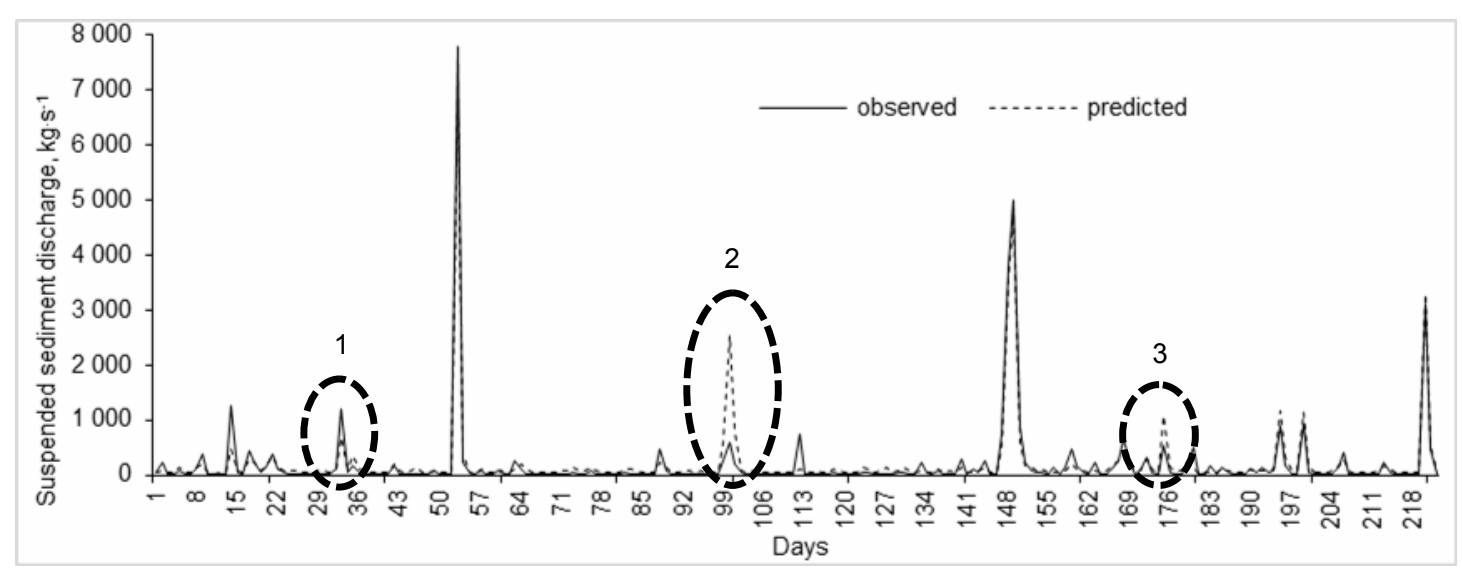

Fig. 8. Time series of observed and predicted suspended sediments discharge; source: own study

data were used for training the model and no negative prediction values for the suspended sediment discharge was observed. This examination reveals that the model has followed the exact pattern of suspended sediment data and predicted the data with an insignificant difference of the observed values. Figure 8 suggested that the MLP model predicted the suspended sediments very closely and the difference between observed and predicted values can be visualized clearly at points 1 ,
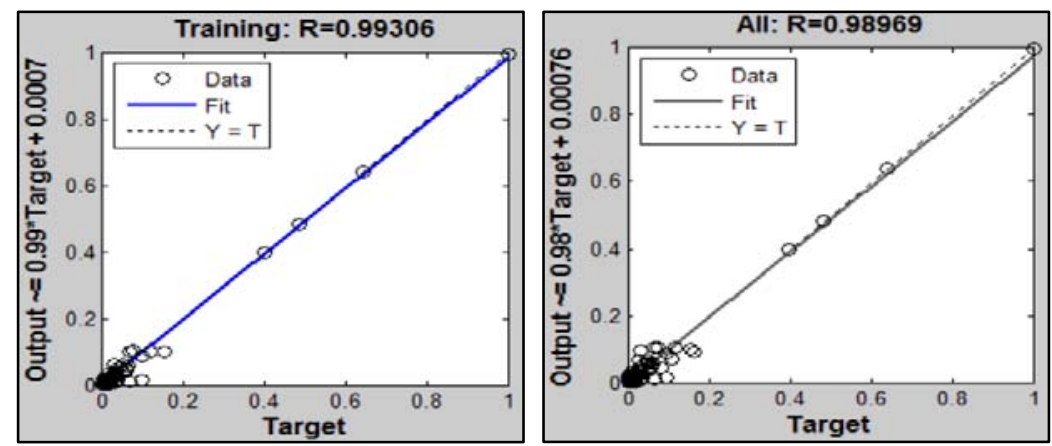

Fig. 9. Comparison between observed and predicted suspended sediment discharge with line of perfect agreement; source: own study

\section{2 and 3. They represent a sudden}

change in sediment discharge (or liquid flow), so the transition of values high to lower values and vice versa.

A comparison of the predicted and observed suspended sediment discharge data with the line of perfect agreement is shown in Figure 9 for training and the whole datasets. The coefficient of determination $\left(R^{2}\right)$ of 0.99 is obtained for both steps. This means that the predicted sediment discharge values are very close to the observed values for all the datasets. The RMSE, $M A E, C E$ are $0.0131,0.00711802$, and 0.98 respectively.

During the study period, the values of flow discharge $(Q)$ as well as the solid discharge from the ANN model on days $t, t-1, t-2$ and $t+1$, were used to estimate the amount of suspended sediment transferred at $7.71 \cdot 10^{6}$ tons corresponding to an annual average of specific solid contribution of 467.78 $\mathrm{t} \cdot \mathrm{km}^{-2} \cdot \mathrm{y}^{-1}$.

The bulk of predicted suspended sediment transport in the Mellah catchment, according to ANNs model, took place in the winter months (Fig. 10). The stream flows and sediment load were higher in the winter and spring seasons (from December to February, March and April) as represented by the downstream of Bouchegouf station. In fact, these months represent $86.95 \%$ of total annual sediment values predicted. As well as, the Figure 11 shows that the predicted sediment load has a reciprocal relationship with the water discharge, and sediment loads appears when the high sediment loads have reached their peaks with the water discharge peak. This is mainly due to more efficient sediment supply and transport during the mentioned months. In the study catchment, sediment 


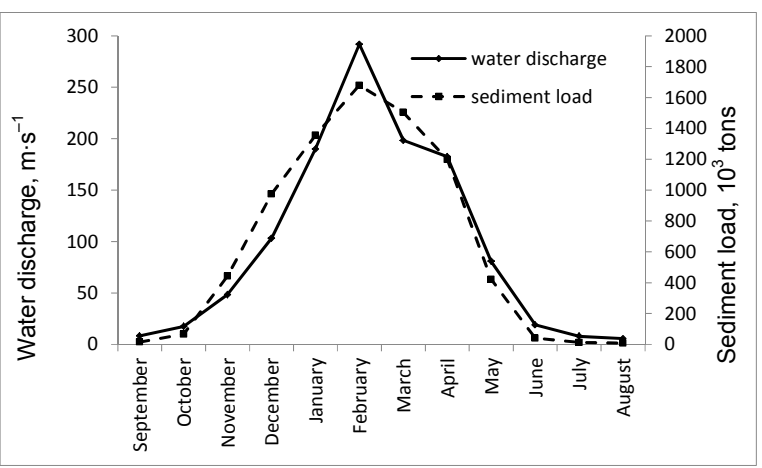

Fig. 10. Monthly distribution of sediment load and water discharge; source: own study

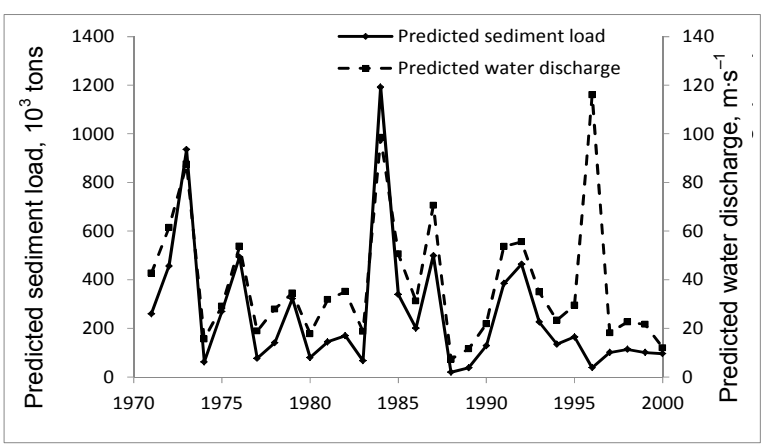

Fig. 11. Annual variation of sediment load and water discharge; source: own study

load has been the lowest during the period June to August and September. On the other hand the autumn months have reached higher values in November with $442.19 \cdot 10^{3}$ tons.

\section{CONCLUSIONS}

ANN was successfully applied for prediction of suspended sediment load at Mellah catchment. The model was tested by applying different input combinations comprising daily water discharges and suspended sediment discharge of the current, the previous day, one and two days before, were constructed. The obtained results showed the robust prediction ability of ANN for the selected time series of the water resource variables. The study suggested that the appropriate application of ANN other than MLPs to the sediment records may lead to solving several problems of water resources engineering and could provide a superior alternative for developing inputoutput simulations and estimation models in situations that do not require modeling of the internal structure of the catchment. In this regard, the developed model presented the prediction of suspended sediment load in the Mellah catchment by using only water discharge and sediment data.

\section{Acknowledgments}

The authors are grateful to the reviewers, in which their advices and comments improved the original manuscript significantly.

\section{REFERENCES}

Alp M., Cigizoglu H.K. 2007. Suspended sediment load simulation by two artificial neural network methods using hydrometeorological data. Environmental Modelling and Software. Vol. 22. Iss. 1 p. 2-13.

ARdiçlioĞlu M., Kişı Ö., HaKtanir T. 2007. Suspended sediment prediction by using two different feed-forward backpropagation algorithms. Canadian Journal of Civil Engineering. Vol. 34. Iss. 1 120-125.

Chang C.K., AZamathulla H.M., Zakaria N.A., Ghani A.A. 2012. Appraisal of soft computing techniques in prediction of total bed material load in tropical rivers. Journal of Earth System Science. Vol. 121. Iss. 1 p. $125-133$.

Cigizoglu H.K. 2004. Estimation and forecasting of daily suspended sediment data by multi-layer perceptrons. Advances in Water Resources. Vol. 27 p. 185-195.

Cigizoglu H.K. 2006. Generalized regression neural network in modelling river sediment yield. Advances in Engineering Software. Vol. 37 p. 63-68.

Cigizoglu H.K., KisI O. 2006. Methods to improve the neural network performance in suspended sediment estimation. Journal of Hydrology. Vol. 317 p. 221-238.

Cobaner M. 2009. Suspended sediment concentration estimation by an adaptive neuro-fuzzy and neural network approaches using hydro-meteorological data. Journal of Hydrology. Vol. 367 p. 52-61.

DAWSON C.W., WiLBY R.L. 2001. Hydrological modelling using artificial neural networks. Progress in Physical Geography. Vol. 25. Iss. 1 p. 80-108.

Demirci M., Ülneş F., SAydemir S. 2015. Suspended sediment estimation using an artificial intelligence approach. In: Sediment matters. Eds. P. Heininger, J. Cullmann. Springer International Publishing p. 83-95.

JAIN S.K. 2001. Development of integrated sediment rating curves using ANNs. Journal of Hydraulic Engineering. Vol. 127. Iss. 1 p. $30-37$.

KaKaei Lafdani E.K., Moghaddam Nia A.M., Ahmadi A. 2013. Daily suspended sediment load prediction using artificial neural networks and support vector machines. Journal of Hydrology. Vol. 478 p. 50-62.

Khanchoul K., Tourki M., Le Bissonnais Y. 2015. Assessment of the artificial neural networks to geomorphic modelling of sediment yield for ungauged catchments, Algeria. Journal of Urban and Environmental Engineering (JUEE). Vol. 8. No. 2 p. 175-185.

KISI Ö. 2004. Multi-layer perceptrons with LevenbergMarquardt training algorithm for suspended sediment concentration prediction and estimation. Hydrological Sciences Journal. Vol. 49. Iss. 6 p. 1025-1040.

KISI Ö. 2005. Suspended sediment estimation using neurofuzzy and neural network approaches. Hydrological Sciences Journal. Vol. 50. Iss. 4 p. 683-696.

KISI Ö. 2008. Constructing neural network sediment estimation models using a data-driven algorithm. Mathematics and Computers in Simulation. Vol. 79 p. 94-103.

KISI Ö. 2010. River suspended sediment concentration modeling using a neural differential evolution approach. Journal of Hydrology. Vol. 389 p. 227-235.

KISI Ö., OzKan C., AKAY B. 2012. Modeling dischargesediment relationship using neural networks with artificial bee colony algorithm. Journal of Hydrology. Vol. 428-429 p. 94-103.

KisI Ö., YuKSEl I., Dogan E. 2008. Modelling daily suspended sediment of rivers in Turkey using several data- 
driven techniques. Hydrological Sciences Journal. Vol. 53. Iss. 6 p. 1270-1285.

LiU Q.J., SHi Z.H., FANG N.F., Zhu H.D., Ai L. 2013. Modeling the daily suspended sediment concentration in a Raihyperconcentrated river on the loess Plateau, China, using the wavelet-ANN approach. Geomorphology. Vol. 186 p. 181-190.

MAIER H.R. 2010. Methods used for the development of neural networks for the prediction of water resource variables in river systems: Current status and future directions. Environmental Modelling and Software. Vol. 25 p. 891-909.

Melesse A.M., Ahmad S., McClain M.E., Wang X., LiM Y.H. 2011. Suspended sediment load prediction of river systems: An artificial neural network approach. Agricultural Water Management. Vol. 98. Iss. 5 p. 855-866.

Mustafa M.R., IsA M.H. 2014. Comparative study of MLP and RBF neural networks for estimation of suspended sediments in Pari River, Perak. Research Journal of Applied Sciences, Engineering and Technology. Vol. 7. Iss. 18 p. $3837-3841$.

Mustafa M.R., Isa M.H., Rezaur R.B. 2011. A comparison of artificial neural networks for prediction of suspended sediment discharge in river - A case study in Malaysia. World Academy of Science, Engineering and Technology. Vol. 57 p. 372-376

Mustafa M.R., Rezaur R.B., Saiedi S., IsA M.H. 2012. River suspended sediment prediction using various multilayer perceptron neural network training algorithms: A case study in Malaysia. Water Resources Management. Vol. 26. Iss. 7 p. 1879-1897.

Nagy H.M., Watanabe K., HiRano M. 2002. Prediction of sediment load concentration in rivers using artificial neural network model. Journal of Hydraulic Engineering. Vol. 128. Iss. 6 p. 588-595.
Olyaie E., Banejad H., Chau K.W., Melesse A.M. 2015. A comparison of various artificial intelligence approaches performance for estimating suspended sediment load of river systems: a case study in United States. Environmental Monitoring and Assessment. Vol. 187. Iss. 4 p. 1-22.

RAI R.K., MATHUR B.S. 2008. Event-based sediment yield modeling using artificial neural network. Water Resources Management. Vol. 22 p. 423-441.

RAJAEE T. 2009. Daily suspended sediment concentration simulation using ANN and neuro-fuzzy models. Science of the Total Environment. Vol. 407 p. 4916-4927.

Rajaee T., Mirbagheri S.A., Zounemat-Kermani M., NOURANI V. 2011. Wavelet and ANN combination model for prediction of daily suspended sediment load in rivers. Science of the Total Environment. Vol. 409 p. 2917-2928.

Sahoo G.B., Ray C., Mehnert E., Keefer D.A. 2006. Application of artificial neural networks to assess pesticide contamination in shallow groundwater. Science of the Total Environment. Vol. 367 p. 234-251.

SARANGi A. 2005. Comparison of Artificial Neural Network and regression models for sediment loss prediction from Banha watershed in India. Agricultural Water Management. Vol. 78 p. 195-208.

TAYFUR G. 2002. Artificial neural networks for sheet sediment transport. Hydrological Sciences Journal. Vol. 47. Iss. 6 p. $879-892$.

TAYFUR G., GULDAL V. 2006. Artificial neural networks for estimating daily total suspended sediment in natural streams. Hydrology Research. Vol. 37. Iss. 1 p. 69-79.

Wang W.C., Chau K.W., Cheng C.T., QIU L.A. 2009. Comparison of performance of several artificial intelligence methods for forecasting monthly discharge time series. Journal of Hydrology. Vol. 374 p. 294-306.

\section{Housseyn BOUZERIA, Abderrahmane N. GHENIM, Kamel KHANCHOUL}

\section{Zastosowanie sztucznych sieci neuronowych do przewidywania ladunku zawiesiny; przypadek zlewni rzeki Mellah w północno-wschodniej Algierii}

\section{STRESZCZENIE}

W niniejszej pracy przedstawiono działanie najlepszego algorytmu sieci neuronowych z użyciem wielowarstwowego perceptronu do przewidywania odpływu zawiesiny ze zlewni rzeki Mellah. Do treningu i testowania sieci użyto serii czasowych dobowego odpływu zawiesiny i odpływu wody z profilu wodowskazowego Bouchegouf. Do oceny działania modelu wykorzystano szereg parametrów statystycznych, takich jak pierwiastek ze średniego błędu kwadratowego, średni błąd bezwzględny, współczynnik wydajności i współczynnik determinacji. Model dawał zadowalające wyniki i wykazywał bardzo dobrą zgodność między obserwowanymi i przewidywanymi danymi. Wyniki świadczą także, że model jest w stanie wychwycić szczegółowy wzorzec odpływu zawiesiny ze zlewni rzeki Mellah.

Słowa kluczowe: modele sztucznych sieci neuronowych (ANN), odpływ, pótnocno-wschodnia Algieria, przewidywanie, zawiesina, zlewnia Mellah 